\title{
Reflexive-Liberative Filipino Feminist Ethics ${ }^{1}$
}

Ma. Theresa T. Payongayong

\begin{abstract}
Filipino feminists have been known to give value to familial relationships, cultural heritage, and religion that are largely influenced by patriarchy. How one aspect (women's emancipation and fight against patriarchal culture) affects the other (women's valuation of family, culture, and religion) in one line of struggle is an important topic to explore, since varied experiences show how some feminists struggle with application of feminist principles to their everyday lives and to women's movement at the same time. Some have had difficulties resolving conflicts between their feminism and social expectations. Others have made equally difficult choices in pursuing and maintaining their intimate relationships. To understand how they deal with these struggles amidst active participation in the women's movement, this paper looks into the emerging feminist ethics among Filipino feminists. The findings identify ethical issues in Filipino feminists' lives and how they address these issues. A reflexiveliberative feminist ethics emerge from the findings. This type of feminist ethics emphasizes choice, and when applied to the women's movement, could lead to a more caring and just society.
\end{abstract}

Keywords: feminism, ethics, reflexive, liberative

I.

$\mathrm{V}$ aried experiences show how some feminists struggle with application of feminist principles to their everyday lives and to women's movement. Some have had difficulties resolving conflicts between their feminism and social expectations. Others have made equally difficult

${ }^{1}$ An earlier version of a part of this paper was presented as "Reflexive-Liberative Activism and Feminist Ethics," in a conference with the theme, Feminist Approach to Women's Empowerment in Korea and ASEAN, organized by the Korea-ASEAN Cooperation Project (KACP) on Education and Exchange Program for Young Scholars in Women's Studies, last 17 October 2012, in Jeju Island, South Korea.

(c) 2020 Ma. Theresa T. Payongayong

https://www.kritike.org/journal/issue 26/payongayong june2020.pdf

ISSN 1908-7330

(cc) BY-NC-ND 
choices in pursuing and maintaining their intimate relationships. To be able to understand how women deal with these struggles amidst active participation in the women's movement, this research studied the ethics of lived feminisms in the Philippines. In the end, these research questions had been answered: What are the ethical issues in Filipino feminists' lives? How do Filipino feminists address these ethical issues? What is the emerging Filipino feminist ethics?

This study aimed to explore the lived experiences of Filipino feminists; fill the gap of lack of knowledge on the emerging Filipino feminist ethics; and contribute to knowledge of Filipino feminist ethics and how it is formed.

As there had been very few attempts to dig deeper into the nature of the ethical dimension of women; as there had equally been no further attempt to focus on what constitutes Filipino feminist ethics and where it comes from; and as various studies presume that both men and women possess certain ethical or moral standards but do not focus on how these standards came to be, the need for a kind of research study that fills the abovementioned lack is in order.

Furthermore, there is still scarcity of written works and studies about feminists' ethical dimension, particularly in the Philippines. There may be works that discuss women's ethical dimension, but only insofar as it is compared to men's ethical dimension. There is none, however, that particularly focuses on how the lived lives of feminists are shaped by their ethics or morality. There is a need to do a kind of study that will dig deeper into the nature of feminist ethics to be able to grasp how feminists live their lives, relate with other people, and affect others in the process.

This study committed to contribute to the enrichment of knowledge on Filipino feminist ethics mirrored in the lives of selected Filipino feminists by emphasizing how feminist ethics could help liberate and emancipate women more.

This study involved self-identifying Filipino feminists who either belong to or have strong affinity with any women's organization or movement. There was definitely conscious effort to make the composition of participants as diverse as possible (like in terms of differences in age, sexual preference, level of education, and occupation). There was, likewise, an effort to represent self-identifying feminists from the various political spectrums. Although efforts had been exerted to ensure variety in the representation of feminists, factors such as, but not limited to, conflict of schedule, proximity, and availability of prospective participants became a hindrance. As a result, all of the participants came from the Luzon area only.

FGD (Focus Group Discussion) and LSI (Life Story Interview) topics focused on intimate relationships and family life. These topics connect the

(c) 2020 Ma. Theresa T. Payongayong

https://www.kritike.org/journal/issue 26/payongayong june2020.pdf

ISSN 1908-7330

(cc) BY-NC-ND 
participants to people close to their lives. Participants are most familiar with these topics because these come closest to their personal everyday experiences.

\section{II.}

There is scarcity of written works and studies about Filipino feminist ethics. Some studies did provide insights on the roles and images of women compared to men. Some proponents attributed it to biology while some said it is based on culture. There is none, however, that particularly focuses on how the lived lives of feminists are shaped by their ethics or morality.

The book, Researching the Fragments: Histories of Women in the Asian Context edited by Carolyn Brewer and Anne-Marie Medcalf, is a compilation of works on cultural and social history of women in Asia. Among the twelve articles in the book, only one article by Mina Roces entitled "Beauty Queen, Moral Guardian, Inang Bayan, and Militant Nun: Images of Female Power in Postwar Philippines" tackled the relation of mother image with women being moral guardians. The usual civic participation of women in society, like charity works and education, is rooted in her mother image. Women are also regarded as guardians of morality, especially in terms of fighting against corruption in politics. ${ }^{2}$

Another book entitled Mga Ina ng Bayan: Life Stories of Filipino and Japanese Women Community Leaders by Amaryllis T. Torres, Marlene G. dela Cruz, and Thelma B. Magcuro discussed the dedication of five Filipino and six Japanese women to community service. Each story presented how these women handled their lives as wives, workers and leaders. The book discussed how these women's lives are affected by their relationship with men. The stories rooted out the usual moral issues that women face in relation to men and the ways such issues are resolved based on gender role stereotyping. ${ }^{3}$

One particular work that came closest to the topic of this study was Sylvia H. Guerrero's Towards Feminist Consciousness: Filipino Mothers and Daughters Tell Their Story. It presented life stories/histories of feminist mothers and daughters from about two to three generations. It discussed influences and external factors identified by mothers and daughters that

2 See Mina Roces, "Beauty Queen, Moral Guardian, Inang Bayan, and Militant Nun: Images of Female Power in Postwar Philippines," in Researching the Fragments: Histories of Women in the Asian Context, ed. by Carolyn Brewer and Anne-Marie Medcalf (Quezon City: New Day Publishers, 2000). See also Mina Roces, Women, Power, and Kinship Politics: Female Power in Postwar Philippines (London: Praeger, 1998), 161-188.

${ }^{3}$ See Amaryllis T. Torres, Marlene G. dela Cruz, and Thelma B. Magcuro, Mga Ina ng Bayan: Life Stories of Filipino and Japanese Women Community Leaders (Quezon City: Milflores Publishing Inc., 2002).

(c) 2020 Ma. Theresa T. Payongayong

https://www.kritike.org/journal/issue 26/payongayong june2020.pdf

ISSN 1908-7330

(c) BY-NC-ND 
affected their consciousness and views on feminism. It also narrated how it is to be raised by a feminist mother. What was given due emphasis here are the values formed from one generation of feminists to another. There are cases when daughters imbibe the values by themselves; some are forced to accept it; while others totally reject it. ${ }^{4}$

A book entitled The Woman of Faith Today: Shaping the Nation's Future edited by Jesselynn Garcia-dela Cruz is a compilation of articles presented during the National Conference on Women in 1997. The articles revolved around the responsibilities of women of faith to address problems of the world. It offered the idea that change is in the hands of women, thus, change should emanate from them. Propagation of faith, life, and love remains part of women's role in society from a religious point of view. It tackled the implications of the religious point of view vis-à-vis men's roles and obligations in society as well as its implications on the ethical dimension of women. ${ }^{5}$

"Coping Strategies of Female-Headed Households in Urban Poor Communities in the Philippines" by Amayllis Torres in Review of Women's Studies is a description of families headed by women from urban poor communities. It discussed the implications of a family set-up like this on the children and on mothers, too. It tackled the influences of being raised in a poor female-headed family on the ethical dimension of children. This work indirectly rejected the idea that differences of ethical dimension are biologybased. ${ }^{6}$

In Sex and Gender in Philippine Society: A Discussion of Issues on the Relations between Men and Women by Elizabeth V. Eviota, sex- and genderbased division of labor was seen as a great impetus for the redefinition of family and the valuation of familial structure based from systematic changes outside the family, i.e., in workplaces, communities, schools, churches, and others. The work pointed to factors that shape a woman's ethical perspective. ${ }^{7}$

4 See Sylvia Guerrero, ed., Towards Feminist Consciousness: Filipino Mothers and Daughters Tell their Story, (Quezon City: University Center for Women Studies - UP Diliman, 1997).

${ }^{5}$ See Jesselynn Garcia-dela Cruz, The Woman of Faith Today: Shaping the Nation's Future, (Quezon City: Office on Women, CBCP, 1999).

${ }^{6}$ See Amaryllis T. Torres, “Coping Strategies of Female-Headed Households in Urban Poor Communities in the Philippines" in Review of Women's Studies, 4:1 (1994), 93-110.

7 See Elizabeth V. Eviota, ed., Sex and Gender in Philippine Society: A Discussion of Issues on the Relations Between Men and Women (Manila: National Commission on the Role of Filipino Women, 1994).

(c) 2020 Ma. Theresa T. Payongayong

https://www.kritike.org/journal/issue 26/payongayong june2020.pdf

ISSN 1908-7330 
Narcisa Canilao-Paredes did a paper on "Ethics in Feminist Research." This work focused on the role of ethics in feminist research but not exactly on what constitutes feminist ethics. ${ }^{8}$

Because of the dearth of local data on feminist ethics, there is a need to surface theories of feminist ethics in the Philippines based from feminists' lived experiences as this study attempted to illustrate.

Compared to local literature, there have been several international studies on feminist ethics. Margaret Urban Walker sets the background for understanding of feminist ethics, discussing women's ways of knowing and how meanings are produced. Her book, Moral Understandings: A Feminist Study in Ethics is useful in evaluating women's sources of knowledge and experiences. It discussed feminist epistemology in connection to the subject of moral philosophy. ${ }^{9}$

Feminist ethics challenges traditional, male-dominated ethics. An interesting work by James P. Sterba, Three Challenges to Ethics: Environmentalism, Feminism and Multiculturalism, discussed recent critiques to traditional ethics, one of which is feminism. Feminism maintains that there is a masculine bias in ethics and purports to show how to correct it. ${ }^{10}$

In "In a Different Voice: Women's Conceptions of Self and of Morality," Carol Gilligan says:

Feminist ethics starts, in one sense, with the realization that Aristotle's famous question in male-stream philosophy does not apply- or has not applied- to women. As de Beauvoir said, women have been objects and not subjects. By that she meant that women have been denied the right to be full moral agents, they have not been those who choose a life. Feminist ethics, therefore, now poses the question: "Is it good for women?" In this way, feminist theorists seek the revisioning of moral philosophy. The feminist imperative is to challenge the hegemony of male ethical theory and to insist on the woman's voice. Feminist ethics, then,

\footnotetext{
8 See Narcisa Paredes-Canilao, "Ethics in Feminist Research," in Gender-Sensitive \& Feminist Methodologies: A Handbook for Health and Social Researchers, ed. by Sylvia H. Guerrero (Quezon City: University Center for Women's Studies - UP Diliman, 1999).

${ }_{9}$ See Margaret Urban Walker, Moral Understandings: A Feminist Study in Ethics, $2^{\text {nd }}$ ed. (Oxford: Oxford University Press, 2007).

10 James P. Sterba, Three Challenges to Ethics: Environmentalism, Feminism and Multiculturalism, (NY: Oxford University Press, 2001).

(c) 2020 Ma. Theresa T. Payongayong

https://www.kritike.org/journal/issue 26/payongayong june2020.pdf

ISSN 1908-7330

(c) BY-NC-ND
} 
arises directly out of women's lives and women's issues. ${ }^{11}$

A female ethics is proposed in Nel Noddings' "Ethics from the Standpoint of Women." Female ethics does not aim to "genderize" morality; rather, it gives value and credence to women's experiences and voices. It does not invoke already established ethical frameworks but takes the standpoint of women based from her lived experiences instead. "The idea is to develop a phenomenology of women's experience that will provide an adequate grounding for the construction of ethics from the standpoint of women." 12

Carol Gilligan in her work, In a Different Voice: Psychological Theory and Women's Development, argued that males and females possess different moral voices but this does not mean that one is superior to the other. She discussed how two children interpret the same moral dilemma differently. The female is concerned about maintaining relationships while the male is concerned with rules and fairness. This correlation is supposed to enhance and complement male-female relationship, not let it degenerate. This fact, according to Gilligan, can be traced from differences of moral development of men and women. Men are impersonal while women are personal when dealing with ethical issues. Logical system and the law are central concepts utilized by the former while the latter considers communication and preservation of smooth interpersonal relationship. In relation to this, men do not really ask for details, they instead directly answer a given moral dilemma. Women, on the other hand, ask many questions, clarify the given, and look for details of the problem before coming up with any position about or answer to a given moral issue. This difference suggests the public-private divide in morality. It appears that men's moral dimension is more public than private. It is public because of the very structural thinking just like the process and system used in various societal institutions. Women's moral dimension is supposed to be private because of the value given to the preservation of emotions and relations like family relations. ${ }^{13}$

Ethics is not something apart from the experiences of individuals. Starting from the self, individuals acquire ideas of ethics and morality as one enters into human relationships in school, church, organizations, and the like. Furthermore, institutions and culture construct practices that direct

\footnotetext{
${ }^{11}$ Carol, Gilligan, "In a Different Voice: Women's Conceptions of Self and of Morality," in Women and Values: Readings in Recent Feminist Philosophy, $3^{\text {rd }}$ ed., ed. by Marilyn Pearsall (USA: Wadsworth Publishing Company, 1999), 314.

12 Nel Noddings, "Ethics from the Standpoint of Women" in Women and Values: Readings in Recent Feminist Philosophy, 388.

${ }^{13}$ See Carol Gilligan, In a Different Voice: Psychological Theory and Women's Development (Cambridge, Mass.: Harvard Univ. Press, 1982).
} 


\section{REFLEXIVE-LIBERATIVE FILIPINO FEMINIST ETHICS}

individuals to act according to what is valued by society at large. Evidently, ethics shapes both the intra- and inter-personal lives of individuals. Surely, whatever ethical principles are acquired from individual, institutional and societal levels of experience, either the principles are reproduced or are modified depending on what goes on between and among people.

Richard Norman distinguishes between two forms of ethics, namely, the substantive or normative ethics, and meta-ethics. Substantive or normative ethics, according to Norman, is concerned with identifying which actions are considered good or bad. In contrast, meta-ethics transcends this concern by analyzing the meaning of good or bad actions instead of merely identifying them. Thus, substantive or normative ethics deals with the "actual use of concepts (good or bad) to talk about human conduct;" while metaethics deals with the "examination of these concepts." 14

Related to Norman's forms of ethics is what Walker referred to as the "two pictures of morality," namely, the "theoretical-juridical" and "expressive-collaborative" models. ${ }^{15}$ On the one hand, the theoreticaljuridical model "prescribes the representation of morality as a compact, propositionally codifiable, impersonally action-guiding code within an agent, or as a compact set of law-like propositions that 'explain' the moral behavior of a well-formed moral agent...."16 Ethics here serves as a system that guides the actions of individuals.

On the other hand, the expressive-collaborative model views "morality as a socially embodied medium of mutual understanding and negotiation between people over their responsibility for things open to human care and response." 17 Ethics in this sense offers certain values that allow individuals to express their feelings, choices, relationships and understandings through shared responsibility.

This study adopted the expressive-collaborative model of ethics or morality for the following reasons: its concept of morality concurs with the idea of feminism; and, just like this sense of ethics, feminism also values the individual expression of feelings, choices, relationships and understandings through shared responsibility.

\section{III.}

This study uses four (4) main domains in the analytical framework, namely, personal characteristics of self-identifying feminists, life experiences,

\footnotetext{
${ }^{14}$ Richard Norman, The Moral Philosophers: An Introduction to Ethics, $2^{\text {nd }}$ ed. (New York: Oxford University Press, 1998), 1-2.

${ }^{15}$ Walker, Moral Understandings, 7.

${ }^{16}$ Ibid., 7-8.

17 Ibid., 9.

(c) 2020 Ma. Theresa T. Payongayong

https://www.kritike.org/journal/issue 26/payongayong june2020.pdf

ISSN 1908-7330
}

(c) BY-NC-ND 
formation of feminist consciousness, and challenges to mainstream/malecentered ethics.

Personal characteristics refer to the demographic profile of participants. Self-identifying feminists are those who consider and actually label themselves as feminists. Life experiences refer to personal everyday experiences while feminist consciousness refers to the understanding of the woman problem and making conscious effort to end the problem. Mainstream/male-centered ethics refers to values imposed by men and concepts of good and bad in accordance to the male perspective.

Personal characteristics of self-identifying feminists are sex, age, education, occupation, and civil status while life experiences are intimate relationships, family life, and involvement in feminism. Intimate relationship refers to a personal, private connection with someone. Family life refers to a set-up or arrangement that accounts for the manners and activities of individual family members. Both personal characteristics of self-identifying feminists and life experiences influence the formation of feminist consciousness. Under formation of feminist consciousness are qualities of being a feminist and feminist values. Formation of feminist consciousness results to challenges to mainstream/male-centered ethics. These challenges are non-traditional concept of family, alternative to marriage, feminist spirituality, and reflexivity of the nationalist and women's movement.

In whole, the analytical framework described the emergence of Filipino feminist ethics.
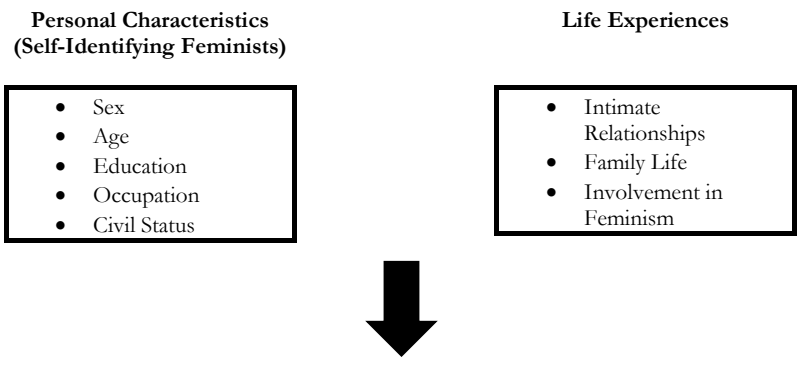

Formation of Feminist Consciousness

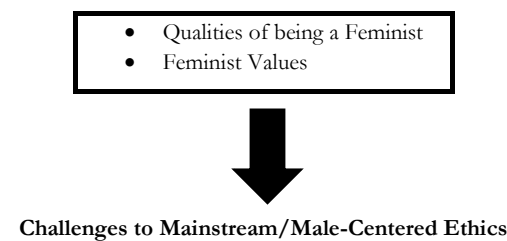

- Non-traditional Concept of Family

- Alternative to Marriage

- Feminist Spirituality

- Reflexivity of the Nationalist and Women's Movement

Figure 1. Ethics of Lived Feminisms Framework

(c) 2020 Ma. Theresa T. Payongayong

https://www.kritike.org/journal/issue 26/payongayong june2020.pdf

ISSN 1908-7330 


\section{REFLEXIVE-LIBERATIVE FILIPINO FEMINIST ETHICS}

Selected participants are self-identifying feminists from various age groups, civil status, and education. These participants represent the young, the middle aged, and the senior who may be married, single or separated and who may be undergraduates, college graduates or post-graduate degree holders. These criteria were set to capture a more complete picture of the lives of prospective feminist participants. Self-identifying feminists are those who consider and actually label themselves as feminists. Most of the selfidentifying feminists who participated in the Life Story Interviews are well known within the women's movement to be either founders of feminist groups or are active in feminist movements. In processing their accounts, the focus was on the participants' personal meanings, experiences, views, principles, beliefs, and values. In analyzing the results, their accounts were interwoven to generate a kind of feminist ethics unique to Filipino feminists.

The author observed ethical considerations in the course of the study. The author secured informed consent of participants; ensured confidentiality of data; respected privacy and personal space of participants; and used pseudonyms to represent each of the participants in the discussion of findings. Personal preferences of participants as well as their rights and dignity as persons were also respected. The author also communicated possible benefits of the study to all participants.

\section{IV.}

This part discusses findings on each of the above domains based on the responses gathered from the Focus Group Discussions and Life Story interviews.

\section{A. Personal Characteristics of Self-Identifying Feminists}

The five (5) indicators that defined the personal characteristics of selfidentifying feminists are sex, age, education, occupation, and civil status.

1. Sex. The twenty-two (22) participants are all women, and three (3) of them identified themselves as lesbians.

2. Age. The participants represent various age group, namely, young, middle aged, and senior. The young feminists are in their 30s while the middle aged are in their 40s. Senior feminists are aged 50 and above. Six (6) are young feminists, eight (8) are middle aged, and eight (8) are senior feminists. The participants' age ranges from 30 to 72 years old.

3. Education. Majority of the participants are highly educated. Four (4) of them are college graduates. Nine (9) participants have graduate 
degrees, and four (4) have post-graduate degrees. Five (5) are high school graduates.

4. Occupation. Half (11) of the participants are NGO workers. Eight (8) are from the academe, two (2) are government workers, while one (1) participant works for the media industry and at the same time serves as a council member of an NGO. Four (4) out of eight (8) participants from the academe also works for an NGO.

Participants whose main occupation is NGO work are involved in various sectors. Four (4) are from NGOs on the women sector; one (1) on women and children; and another one (1) on women and fisherfolks. One (1) NGO has programs on farmers and fisherfolks; one (1) on farmers; and another two (2) on fisherfolks. Only one (1) NGO focuses on labor.

5. Civil Status. Half (11) of the participants are married; two (2) are single (one is a nun, and the other has a child); three (3) are in domestic partnership (two of them are in same-sex relationship, and one is in an incestuous relationship); three (3) are separated (one of them has a partner but they are not living together); and three (3) are widows (but one of them currently has a partner).

\section{B. Role of Life Experiences in Shaping Feminist Consciousness}

Along with personal characteristics, life experiences play a role in shaping feminist consciousness. These life experiences refer to intimate relationships, family life, and involvement in feminism.

1. Intimate Relationships. Participants define intimate relationship based from their experiences. They mention qualities to maintain intimate relationship. Some of them identify challenges to it.

\section{Definition of Intimate Relationship}

Participants associate intimate relationship with private property. One participant, Loreta, shares that "being intimate is an issue of one being a property of the other. You are mine, I am yours ... If you want to philander around, our intimate relationship ends."

On the ideas of exclusivity and mutuality, they believe that there should be no other parties involved. Once another party enters the scene, it breaks the exclusivity clause and alters the character of the relationship. One adds that it would be hard for her to be in an intimate relationship with two or more individuals such as a 'threesome.' For her, the concept of 'sharing' in this case, is repugnant.

(c) 2020 Ma. Theresa T. Payongayong

https://www.kritike.org/journal/issue 26/payongayong june2020.pdf

ISSN 1908-7330 


\section{REFLEXIVE-LIBERATIVE FILIPINO FEMINIST ETHICS}

The participant in the same-sex relationship shares that she finds it easier to connect with another woman and because she and her partner share the same values, they are exclusive or monogamous by choice. Jonet points out that "actually, it is no different from a heterosexual relationship. We are exclusive; we are monogamous not because we require each other to be so but because the values of each one come into play."

Another participant, Josefina, adds that intimate relationship need not be within the bounds of marriage and between opposite sex. Melinda shares her incestuous intimate relationship with her third-degree cousin. She says, "what makes the relationship complicated is the fact that my partner is my third-degree cousin. The ethical issue is, therefore, glaring. He is my third cousin, he's younger than me, and we live together. This is our shared level of intimacy."

\section{Qualities to Maintain Intimate Relationship}

There are qualities of an intimate relationship that the participants believe should be maintained. It is important to be friends, according to Nita, Aurea, and Lucia. Melinda, on the other hand, considers her partner as roommate or companion. Aurea also shares that it is important to have constant communication.

Nita adds commitment and respect for each other. She says,

The only thing consistent in us is that we're friends. Sometimes, I don't want this anymore, I can't take this anymore. He is also like that. There are times when you say, "I'm fed up." That's when you no longer feel the excitement, you feel excited about other people instead. But what is consistent here is we are friends. We just have to respect each other because we already have two children."

Jonet also says that she values commitment. "I am committed with this person. Because I have a commitment, even if I fell in love with another, I made the decision to keep this relationship."

Independence is also valued. Aurea keeps her own money while her husband keeps his own. Nita says she has her own activities or projects separate from her activities with her husband. Josefina and Jonet add that it is important to maintain one's own identity within a relationship, and that the relationship has to be nurturing so as to enhance each other as a person. Jonet shares,

(c) 2020 Ma. Theresa T. Payongayong

https://www.kritike.org/journal/issue 26/payongayong june2020.pdf

ISSN 1908-7330

(c) BY-NC-ND 
What should happen within a relationship is that your person is enhanced, it develops more. So, even when you separate ways, no one is devastated, instead, you'll get out of it complete and whole, and so much more because of the learnings and experiences you got from your relationship no matter how long or how short the relationship may be.

According to Aurea, Lucia, and Perlita, it is important that the spouse is as much a part of, or supportive of, the activist or revolutionary movement. It is also important that the spouse is supportive of their feminist ideals. Because of this, Aurea says, she and her husband never had major problems; the secret to their happy and peaceful marriage is the application of feminist values in their lives.

\section{Challenges to Intimate Relationship}

An issue regarding Melinda's intimate relationship is that she recognizes the economic disparities with her partner. She says, "It's also not equal because I am more dominant not only in decision-making but also in terms of finances, because I have a higher salary. I have accepted that we're really not equal."

There is also unequal gender division of labor in Lina's case. She shares, "taking care of the children is automatically mine. But he has other priorities. He has work, he tends to go home late. He still wants to stay out at eight o'clock in the evening." This is also true of Xenia's case. According to her, "my husband arrives, I make him coffee, serve his food, wash his clothes, while I take care of our children. It seems those are my set roles as his wife. Until I joined a woman's group where I had trainings on how to stand for women's rights."

Before, Perlita's husband had an opinion regarding the tasks for women and tasks for men. Ten years ago, they both decided that her husband should add one household task in what he is doing, that is, doing groceries. He is doing that until now. Perlita adds,

In principle, aside from the fact that he is hands-on with the kids, he has a household task that is agreeable for him, so that it is also clear to himself, to his integrity, to his kids, that household tasks should be done and that it is not demeaning. 
For other participants, in contrast to marriage, non-traditional relationships work for them. Even if uncertainties in their relationship continue to hound her, because she is into a domestic partnership, Melinda continuously makes effort to make it work and plans to stay as long as they live harmonious lives and they do not hurt each other.

Remedios also lives with her same-sex partner. She says she is happy with the set-up. "They knew we shared a home, we bought it. That's what we want-we're independent, we're together." For Carmen, who had gone through two previous marriages, and now has a partner, traditional relationship does not work for her. At present, she has a partner but they do not live together.

Five participants, Melinda, Nita, Lina, Loreta and Ana share a common experience. Their husbands/partners had an affair with other women. Melinda says she drove her partner out of the house when it became clear that she cannot stop her partner's affair."I don't know if I'm wrong, I drove him out of the house right away. I don't want to be at the losing end ... I think this is the most painful that ever happened to me."

Unlike Melinda, it was Lina who left the house. Lina reasons out that she is working for gender issues and helping other women, yet she had a problem with her husband's infidelity. Eventually, the need for someone to be always there for her prevailed.

Instead of getting separated, Nita proposed an open relationship. She explains, "you know, if you have a relationship, you have expectations, right? So, remove the concept of relationship and you wouldn't have expectations." In the end, they reconciled. Nita also learned to lower her expectations in the relationship and be independent from her husband.

We no longer talk about sweet nothings. Mushy expectations are gone. Maybe we have matured over time. When there's a party and he does not invite me to come with him, I don't feel hurt anymore because I also have a party to attend to. And then before, it was an issue when we do not share the same bed. Now, we more often do not share the same bed. We have separate beds. After it happened, there's a possibility of separation. What is important, and my kids know it, with or without a partner, you have something you can call your own. After it happened, my conviction to have my own house is strengthened, I will build my own, what I can consider my own.

(c) 2020 Ma. Theresa T. Payongayong

https://www.kritike.org/journal/issue 26/payongayong june2020.pdf

ISSN 1908-7330

(c) BY-NC-ND 
Loreta shares how she handled the situation when she found out her husband had another woman. She says, "along the way, he had a third party. I declared then, 'let's separate because you're no longer mine, and I'm no longer yours. I don't want to share you with another woman.' It's also difficult. Of course, you know the nitty-gritty and the implications of separation-children's interests first, the length of the relationship, your history together."

2. Family Life. Participants describe their actual family set-up. Child-rearing experiences from their immediate and current families are also shared.

\section{Family Set-up}

Participants share various forms of family-single, nuclear and extended. Paula says it is important that there is a bond between and among people whom you consider as family. She shares, "I'm a single parent. My concept of family is that you have a stong bond. I don't believe that to become a family there should be a mother and a father. Blood relation binds me with my daughter. So, she is my direct family."

Paula, Sheila and Joana say that there could also be an extended family. Paula's experience is that, "the other extended family includes the parents, grandparents, there is also bond there. Then there is the 'movement' that binds you beyond blood."

Sheila says, "now that I belong to a movement, my family has grown bigger." Joana adds, "the people whom I offer my life, time and actions to are my family."

Jonet considers same-sex partners as family. She shares, "I'm now within a non-typical family. Me, my partner and her two kids. This is our family, including the cat." Melinda adds childless couple as a kind of family, too. She says, "it's also a family even if [the couple is] childless and has no benefit of marriage."

In a broader sense, participants extend family to non-relatives, such as members of organizations and movements to which they belong. Loreta includes non-humans, like birds, plants and animals as family. "I belong to a traditional family. With husband, children, including dogs, birds, plants."

\section{Child-Rearing Experiences}

Child-rearing experiences affect the formation of feminist consciousness. In turn, it also affects the way feminists rear their own children. Feminists either adopt or reject the child-rearing practices they experienced in their own method of child-rearing.

(c) 2020 Ma. Theresa T. Payongayong

https://www.kritike.org/journal/issue 26/payongayong june2020.pdf

ISSN 1908-7330 
Four of the participants say they have strict and traditional parents while six say otherwise. Carmen says that her mother is submissive to her father and even to her father's siblings and her in-laws. It was her grandmother who taught her how to fight for her rights and how to be independent.

Remedios says her parents were disciplinarians; there were many restrictions in their childhood. Her parents also favored the only son over her and her sister. Rowena shares that her parents were more protective of daughters than of sons. Lina says she was compelled to obey her parents all the time and not to argue with them. She also does not share her problems with them but with older cousins.

In comparison, the rest of the participants say their parents were not strict at all. Susan claims that her parents did not impose rules. Both Nita and Melinda say that their parents were not strict; they were given permission to attend parties or to go anywhere they wanted to go.

The parents of Nita and Perlita were also liberal in terms of sexuality. Nita's parents did not forbid her from accepting suitors or from talking about her crushes. Perlita also recalls her mother saying, "You know, only kind and religious women get pregnant. There are available contraceptives, [just] in case."

With regard to their own children, the participants are as liberal or more liberal than the type of child-rearing practices they experienced. They enumerate several examples to prove this.

Jonet and Josefina share that it is good to have rules in the family. Jonet values open communication as a basic rule in her family. Josefina agrees with Jonet and adds, "It is important, especially while kids are still young. Because children feel safe with routine."

Lina says she does not impose too many rules; in fact, there are only a few. She also lets her children explore and express themselves. Nita recognizes the importance of open communication; her children can talk freely about anything.

When it comes to toys, Lina and Perlita let their children decide whether they will choose toys for boys or for girls. Meanwhile, Rowena prefers gender-neutral toys, like stuffed toys, building blocks, and books.

Assignment of household tasks varies. In Remedios' case, all her siblings, whether male or female, had responsibilities and duties in the household. Lina says it depends on who is more hardworking. More often, children in their family were spared from household tasks. It is the same with Nita; older children have more responsibilities.

Both Nita and Rowena do not believe and veer away from physical punishment as a form of child discipline. In fact, Rowena says she felt guilty when she hit her child, and she never did it again.

(c) 2020 Ma. Theresa T. Payongayong

https://www.kritike.org/journal/issue 26/payongayong june2020.pdf

ISSN 1908-7330

(c) BY-NC-ND 
According to Perlita, her children recognize that, as a mother, Perlita is involved in certain decision-making processes, such as the reproductive aspects of the children's lives.

When it comes to sexuality, both Perlita and Rowena give informed choices. Perlita says it is her children's choice whether to adopt or reject mainstream values. Perlita says:

I explain to my children why I do those things. Here are the mainstream values, assess yourself. Then the feminist way of living is there. When they ask about sexuality, physiology, questions of what is my morality regarding those things, I answer them without hesitation.

Rowena says:

I'm also not strict in terms of their intimate relationship. I only have a rule. When my daughter started menstruating, I just said, don't have sex because sex can get young persons very crazy in their head. But if you cannot avoid it forwhatever reasons, just make sure you protect yourself. Don't ever get pregnant against your will. I just reverse it with my son. I just assume that they will be sexually active.

Aurea shares she supported her eldest daughter who is a lesbian. Her daughter has a same-sex partner, who has a child. This child Aurea accepts and treats as their family's own, as their first apo. When her daughter is still in the process of coming out, Aurea was there to help her out. Aurea accompanied her to various libraries; she lent her daughter books to read. In the end, when her daughter decided to come out, Aurea and family fully supported the daughter. Aurea has always been proud of her eldest daughter. When it comes to child's play, Nita and Lina have different experiences. Lina says boys and girls play together while Nita says boys excluded the girls, and that boys spent more time outside the house.

Two participants say their views on sexuality were influenced by older cousins and the liberal atmosphere in college. Lina recalls her older cousins having boyfriends and talking about the changes in their bodies. 


\section{Conflict with Household Help}

Loreta shares how conflict with their household help becomes an issue. She says:

I have issues with my helper. There is conflict of space between her son and my children. The question of who is going to discipline my helper's child arises. I recognize though that the child and my helper have their own dynamics. I also feel for my helper as she is a single mom and I know it would be difficult for her if I let her go.

Jonet adds, "We have the same problem with our former helper. Of course, we don't tell her not to bring her child with her. But the problem is, the child's presence invades our privacy." Ana also mentions privacy and space as main reasons why she does not want household help.

3. Involvement in Feminism. Responses show that participants' involvement in feminism are rooted in their activism - through student movements, NGOs, and revolutionary movement. The participants are activists first before becoming feminists. Others trace out their involvement in feminism through the academe. They are also referred to as intellectual feminists.

\section{Activists as Feminists}

Even when she was a student, Carmen recognizes the inequality between men and women, particularly in the movement. Carmen also shares that they do not have women's issues in the agenda.

Rowena also says that her becoming a feminist was rooted in her experiences as a student activist since the First Quarter Storm. For the majority, feminism comes much later in the course of their involvement in nationalist organizations.

Susan adds that she started to become a feminist when she interviewed violence against women (VAW) survivors during a forum of the World Council of Churches in 1977.

Like Susan, Nita says her ideology then centered on nationalism, and not feminism. She adds that she did not experience oppression, only learned more about feminism when she was tasked to write a module on women's issues in the academe. She says, "feminism has nothing to do with my line of work. Our ideology is centered on nationalism. Because I have no experience of repression as a woman, I can do whatever I want."

(c) 2020 Ma. Theresa T. Payongayong

https://www.kritike.org/journal/issue 26/payongayong june2020.pdf

ISSN 1908-7330

(c) BY-NC-ND 
Lina was introduced to feminism by a colleague. Carmen learns about the term, "feminism" when she joined a women's organization. Rowena said her appreciation of feminism is more on the theoretical side. She says she has no feminist consciousness then, but she already had gender questions.

We were reading Kate Millett. Our appreciation of Kate Millett is theoretical. My friends and I were exposed to feminist literature but we never called ourselves feminists. It was taboo. We were not allowed to think within the movement. I mean there was not time and we were not encouraged.

Rowena adds:

But I [had] a question about marital relations. I [had] questions about why our bosses were males. I mean, we never called them "boss." Anyway, so we were imprisoned. I think the sexual torture, it is another layer. So, there's layering of questions like "why [were] women the [only] ones sexually abused although men were also tortured?"

Some of these women even went on to pioneer feminist or women's organizations in their time. Carmen shares that Women for the Ouster of Marcos and Boycott or WOMB was formed before GABRIELA. Also prior to GABRIELA, Susan and three other women put up a women's movement called FILIPINA, which was born after the UN Decade for Women, a parallel NGO forum alongside the government-sponsored forum.

Another organization called Katipunan ng mga Kababaihan para sa Kalayaan was formed which, according to Rowena, was the first mainstream feminist collective.

Lina shares that from their labor organization, they decided to organize a separate women's organization, MAKALAYA. Because Lina was a member of an international union, her organization was also influenced by the international trend of having gender or women's activities.

\section{Intellectual Feminists}

Four participants claim that the turning point of their feminism was through the academe. Although Melinda says that her feminism is deeply rooted in her experience of sexual abuse, being a feminist came much later. 
According to her, "my experience of sexual abuse is a factor but my turning point as a feminist was when I entered school. It is in Women and Development degree program that I became a feminist. Although my first job was in ISIS, I do not categorize myself during that time as a feminist." Remedios shares the same experience. She says she learned feminism from the books, and she describes her involvement in a women's studies program as academic in nature. Loreta says she practically grew up in the academe.

Lani adds, "of course, UP education, your exposure, it helped reinforce what you think you already believe in. Because if you do not value women's rights before, you [will] not [be] exposed to it, whatever you learn wouldn't appeal to you."

\section{Formation of Feminist Consciousness}

The formation of feminist consciousness is based from personal characteristics and life experiences of self-identifying feminists.

1. Qualities of Being a Feminist. The participants identify several qualities that they possess as feminists, like independence, decisiveness, assertiveness, integrity, and critical thinking. Participants also mention other qualities perceived as strengths and weaknesses. Strengths include self-trust, resilience, and objectivity; while weaknesses are lack of self-confidence and being emotional.

\section{Independence}

Lina claims: "I became independent because they let me have my way. I'm more open to exploring things. Because I was surrounded with many people in our home; many discussions were also allowed at a time when children should not be exposed to such discussions."

Rowena also says it is important to be economically independent. She shares that her mother maintains a business up to now and always keeps herself busy.

\section{Decisiveness}

Susan says she stands by her decisions, even if they go against the opinions of the majority.

The moment you make your own decision, what you want to believe in, the absolute will no longer have a

hold on you. You take it freely but then you are free to

(c) 2020 Ma. Theresa T. Payongayong

https://www.kritike.org/journal/issue 26/payongayong june2020.pdf

ISSN 1908-7330

(c) BY-NC-ND 
believe in something else. Like what I said in my confession today, 'Father, there are many Church teachings that I had already put in the archives. I'm not throwing it away because it might be helpful to others, but it doesn't make sense to my life so it is there in the archives.

\section{Assertiveness}

Carmen says assertiveness is needed in fighting for women's rights. "Because it is no longer possible to have a strong women's movement that will set women and the people free without a kind of ethics requiring you to really stand and fight. And in fighting, there are many forms of assertiveness needed."

\section{Integrity}

Perlita discusses integrity in relation to how she values the insight that the personal is political. "You need to evaluate your own actions, as well as your responsibilities. At the same time, you are looking at the larger picture, the external or social reality. You should have integrity in both areas. There should be no conflict with what you do externally from what you do internally."

\section{Critical Thinking}

Perlita says critical thinking is important but, at the same time, it has emotional dimension. "Do not accept blindly what culture tells you. If you need to accept it, you have to make sure that you really thought about it. And if you think that it is not correct, that it is immoral, then go ahead and reject. From the very beginning, you already have a critical stance."

\section{Other Qualities}

In terms of strengths, some participants mention self-trust, resilience, and objectivity. Nita explains that self-trust emanates not from her skills but from her convinctions. "My strength I get from self-trust; my self-trust I get not from my skills but from my conviction. It is more of conviction than skills." Lina says she has the ability to objectively view the issues at hand instead of being affected emotionally. Melinda says she is able to cope with any problems because she analyzes it. 


\section{REFLEXIVE-LIBERATIVE FILIPINO FEMINIST ETHICS}

In terms of weaknesses, Melinda and Lina say they lack selfconfidence. Lina says she does not want to be in the limelight, and she knows that there are more deserving, who are more articulate in explaining issues than her.

Nita says she gets emotionally affected with the VAW cases she is handling. "My being emotional is my weakness to the point that I cannot handle objectively, for example, a VAW case-she's telling her story, I still couldn't help myself but cry. I will still cry."

2. Feminist Values. The participants talk about their values as feminists. Among the values they share are motherhood and family as well as work and contribution to society.

\section{Motherhood and Family}

Lina says being a mother is, in itself, an achievement. She adds that recognition from the family that she is an activist is also a personal achievement. Family is very important, and it has a critical role in the lives of some participants. It is described as a refuge and support group, especially during critical moments in the participants' lives, like Rowena's.

You know when I was an activist, I think family is less implortant. Although there were critical moments when I realized it's still my family that will be my support system. When I was with the UG movement, situations are very difficult for us. We were being chased. I realized, looking back, that during critical moments, my family is still my refuge. When we were being chased, my family is the first to be harmed. They have developed strategies just to protect us (me and my husband).

Because Carmen was busy with her activist work, she was not able to prioritize her children. Rowena says her family had no important role when she was an activist. All these changed when they each experienced personal dilemma. "Yes, it is only now that I realized that it is important. In fact, I realized how important my family is to me more than anything else when my twenty-two-year old son died. Of course, because I was a full-time activist, I realized late that, more than anything else, family is the most important for me."

Lina describes her family as very supportive and understanding of her activism and helpful anytime she needs help.

(c) 2020 Ma. Theresa T. Payongayong

https://www.kritike.org/journal/issue 26/payongayong june2020.pdf

ISSN 1908-7330

(c) BY-NC-ND 


\section{Work and Contribution to Society}

For Nita, her greatest achievement is work-related: supervising a general education program at Miriam College, and receiving a scholarship. Carmen says managing a television station that is traditionally dominated by men is an achievement.

The participants also mention their contribution to society. Lina says the sisterhood in MAKALAYA enabled many women to find their own voices and assert their rights.

Here's a woman who is quiet at first, she almost wouldn't utter a word, then she will make her presence felt. She really asserts her opinion. I think it's not only the skills, but the sisterhood. They can speak out within the organization which they know will not judge or condemn them.

Susan says her legacy is creating awareness on women's issues. She also cites that her founding an institute helped a lot in creating awareness.

My contribution to society? In the Philippines, it's the awareness of the women's issue. I think that we contributed to [a lot of people's] awareness because we had many protests already in raising the consciousness of people on women. So, I think that's what I would consider as my legacy.

For Carmen, her work in a television station enables her to utilize the power of broadcast media to promote women empowerment.

I am able to use the power of broadcast media to change the view on women, and for media not to become a medium to further perpetuate the disempowerment of women. We were able to communicate well to the community that women have rights ... we have no programs on, or we impose strict policies in relation to, the portrayal of women as sex objects. We do not accept any advertisements with that kind of message. We are a community television and we conduct regular shows with discussion with the different sectors. 
For Perlita, both she and her husband have a contribution to society. "Our great contribution to society is the fact that my husband earns more than enough so I can be free to engage in the social movement. He really provides most of the material goods for the family."

\section{Challenges to Mainstream/Male-centered Ethics}

From the participants' qualities of being a feminist and the feminist values they uphold, there are many challenges to mainstream ethics that emerged. These refer to non-traditional concept of family life, like same-sex relationship, and childlessness; and alternative to marriage like cohabitation, emerging feminist spirituality, and reflexibility of the nationalist and women's movements.

Susan says patriarchy has been shattered; women have gone a long way, but we still have a long way to go.

I think we have gone a long way; the fact that a rape victim sues .... During old days, she will not sue. She will be ashamed. The fact that those guilty of incest are convicted. And the fact that we win cases in court. The fact that you're doing this. And not only that, not only you, grade schoolers, high school. They come and interview about women. Oh, 20 years ago, they wouldn't have known anything about women. You know that they are not conscious about women.

She adds:

I think we have shaken patriarchy. We have gone a long way. But, of course, we still have a long way to go. Because we haven't reach[ed] many people. For me, we have made a breakthrough. We lobbied for women's agenda with the government, with the church. They cannot anymore ignore it.

\section{Alternative to Marriage}

Five participants say they do not believe in marriage or they do not want to get married. However, Rowena recalls being pressure by her husband's parents, who wanted them to get married. "I secretly got married only to please my husband's family. That really was a cause of big disappointment to my husband's family, my in-laws. Because he is the eldest

(c) 2020 Ma. Theresa T. Payongayong

https://www.kritike.org/journal/issue 26/payongayong june2020.pdf

ISSN 1908-7330

(c) BY-NC-ND 
and a Batangueño which is very patriarchal. His father's dream is to prepare a huge feast."

Perlita shares that her husband threatened to leave her if she will not marry him. "He said he will leave me if I don't marry him. Because his vision in life is to get married. I don't want to be left behind; I love him anyway. So, I married him."

Melinda mentions marriage as not a guarantee of lasting relationship nor a guarantee that the partner will be faithful.

I don't want to get married. Fresh into separation, I thought if we became family, would he even think about cheating [on] me [with] another woman? I was also the one who answered, 'Yes." What is your guarantee, even if you're married? You cannot have [an assurance that] marriage will lead to an ever after. A lot of things can happen, and relationship is fluid. Even older people separate ways. There is no security.

Remedios recommends cohabitation, provided that it works for the couple, and it suits their personalities.

I think if they want to, why not? I'm not saying I will recommend it because I think it is the best but well, in any relationship, there are problems and issues. I'm sure mine is not without struggles. I don't think it has anything to do with the set-up; I think it would be basically personality. Supposedly, she will support my career; I will cheer her on her career. If there's a problem, we would just make sure that whatever happens, we split our properties equally.

\section{Non-traditional Concept of Family}

Jonet prefers same-sex relationship to a heterosexual one. "But I think it's easier for me to be intimate with a woman because of so many reasons. You're more at ease. In a way, it is less complicated because you will not get pregnant, it's easier to connect with another woman." Melinda adds that childlessness does not affect her idea of a complete family. "It's also a family ... even if childless and has no benefit of marriage." 


\section{Feminist Spirituality}

For activists who have considered themselves atheist or agnostic, Rowena says there is a shift; they find themselves on a spiritual journey.

Another emerging, if it has not emerged yet, is feminist spirituality. Because I have a number of friends who came back to the religious framing of their spirituality. There are many KALAYAAN who went on spiritual journey ... In many ways when you joined a party or a strongly centralized group, as we say, it's probably a form of religion by itself. And then when you're out of it or trying to get out of it, and realign yourself with others, another movement, you look for something to hold on to.

Susan, a nun, says she learned to dwell into other religions aside from Roman Catholicism. She says there is no contradiction there if one can live with it.

Right from the start, contemplation is very important to me. When I became an activist, it softened a little because, I reasoned, the things I do, it's already prayer. But I realized it couldn't be. And do you know what gave me my contemplative life? I got into Buddhism. That led me to study all religions. I felt I have the right to gather what are the jewels in these religions. Because what I saw was, what is God? Is God so unfair that only Catholics will go to heaven? I saw the beauty in contemplation, and it did not go against my activism.

Why is everybody looking for artificial contradiction? Here is contemplation, here is action. Either you are an activist or a nun. "Why are you in GABRIELA when you are a nun?" When I'm with GABRIELA: "why do you meditate?"

If I can live with it, then it is not a contradiction. No regrets at all. I could not have led a more meaningful life even if I tried to.

Rowena says her spirituality changes over time.

For a long time, I was [an] atheist. To soften the joust on my children, agnostic. When I was an activist, I'm an atheist. Lately, when my father died, and then, my brother, my views are changing because a lot of my friends after Martial Law years, and then activism, then

(c) 2020 Ma. Theresa T. Payongayong

https://www.kritike.org/journal/issue 26/payongayong june2020.pdf

ISSN 1908-7330

(c) BY-NC-ND 
prison, many of them turned to religion. I suppose I'm also in a journey in the way of my generation. [sic]

\section{Reflexivity of the Nationalist and Feminist Movements}

In general, Perlita says the ethics of the nationalist and feminist movements should be challenged from time to time.

Even the movement needs to challenge itself all the time about ethics, even the ethics of the women's movement. It is not completely oppositional or resistive, right? As they say, no one died and went to feminist heaven. We are still part of this society and many of the things that we want to change, we bring with us, and maybe unconsciously it is still there. A most shallow experience here is that many feminists shout at co-workers, shout at household helps. Many feminists use the ideas of fellow feminists so they will become popular, so they will earn from it, elevate their career. On the other side, debate among feminists can get acrimonious and binary. It's not a question of the feminist movement against the male. The feminist movement in itself continues to be selfreflexive about what it's doing, what it's trying to achieve.

Ana shares her frustration with the feminist movement saying, "it's frustrating; I have no problem with differences in views but not to the extent that we will take it against each other. Sisterhood is powerful and it should unite women on issues affecting them."

Anabel also shares her personal conflict with another feminist when the latter became Anabel's husband's other woman. She says, "My husband's other woman is a feminist. She does not care if, in the process, another woman will suffer or a family will be broken."

Another issue that is prevalent in the feminist movement is the insight that the personal is political. Rowena says that before, marital problems and gay issues were not made public. Eventually, these issues are being addressed.

Some participants share their struggles on the inclusion of women's issues in the nationalist or revolutionary movements to which they belong. They also say the movement should also take into consideration women's control over their bodies. According to Rowena, "within the Party, it is not

(c) 2020 Ma. Theresa T. Payongayong

https://www.kritike.org/journal/issue 26/payongayong june2020.pdf

ISSN 1908-7330

(cc) BY-NC-ND 
allowed to have sexual intimacy. The Party is more Catholic than any Catholic. It has sexual rules."

The Party does not allow unmarried couples living together. Although there is divorce, it is not easily granted. Rowena adds,

Although divorce is allowed, you cannot just separate. Even if you say your misunderstanding is too much to bear already, you don't agree anymore, because the question to you always is, 'Are you divided in political line?' When you answer no, then you are not allowed to divorce. Remember, it is not even allowed for partners to live-in. You need to get married.

Rowena says even getting pregnant is planned, "it has to be planned because resources will be needed for your personal security." According to Rowena and Lina, the assertive women in the movement experienced criticisms from men, and even women. Lina says men belittle women's issues. Women were also branded different things: "we were attacked by our own comradespeti-bourgeois, lesbian, nymphomaniac, bra-burning, unhappy housewife, all you need is good sex-we heard it all."

Rowena says there should not be hierarchy of class over gender. She adds that women's freedom is not guaranteed by the country's freedom. Both Rowena and Lina went on to form autonomous women's movements. Feminists from different generations also have different concerns. Rowena points out that feminism is dynamic.

This young woman, she wants to establish a union for labor rights. But in the portion of sexuality, [in] our issues as women, she has no hang-ups. There's nothing wrong with flaunting your body, nothing wrong with having multiple sex partners. In fact, they find nothing wrong with prostitution. I think their ethical parameters are also changing. In my view, it is generational. Who am I to judge them?

In my view, the younger women, younger generation are building their own kind of ethics whether they're good or bad. Eventually the ethics of feminism will be defined by the activists themselves or the advocates in much the same way that the feminist literature in the West have. Then we also do not believe that feminism is static. We think it is changing.

(c) 2020 Ma. Theresa T. Payongayong

https://www.kritike.org/journal/issue 26/payongayong june2020.pdf

ISSN 1908-7330

(cc) BY-NC-ND 
V.

\section{Ethical Issues in Filipino Feminists' Lives}

Based from the findings, ethical issues arise out of intimate relationship, family life, and involvement in feminism. Women are expected to subscribe to traditional concepts of intimate relationship and family life; otherwise they will face ethical dilemmas. They are supposed to maintain a nuclear family; get into an intimate relationship only if married; keep the marriage and family intact at all cost; accept that it is alright for men to philander around; and manage the household tasks.

In addition, if they choose to be involved in feminism, they will, likewise, face ethical dilemmas. Women's issues are not prioritized in maledominated movements whose main thrust is class and nationalist struggles. There is also unequal relation of men and women within the movement as reflected in unequal role assignments once women give birth. Women's pregnancy is planned, and there is little recognition of the reproductive rights of women. Why is this the case? Filipino women are viewed in Philippine society as weak, passive, submissive and dependent because of the patriarchal culture.

\section{How Ethical Issues are addressed by Filipino Feminists}

As feminists, they do not blindly and immediately accept or reject life decisions that are dictated by tradition. Instead, they critically examine and subject these life decisions to careful scrutiny and evaluation before they either reject or accept it. Rejecting it may mean total disregard of tradition, while accepting it may mean striking the balance between tradition and feminist values. Either of these may have good or bad consequences but what is important is that feminists stand by their informed decision.

\section{The Emerging Filipino Feminist Ethics}

The Filipino feminist ethics that emerged out of this study is what the author refers to as reflexive-liberative. It is reflexive because feminists have choices and understand the choices they make. They either reject or accept mainstream/male-centered ethics based on whatever works for them and other people. Reflexive further means continuous self-examination where ethical decisions are based on changing contexts and situations and in consideration of the greater good. It is liberative because the choice is supposed to be not only for the benefit of feminists as individual or group, but for humanity as a whole. The feminist as a moral agent determines the

(c) 2020 Ma. Theresa T. Payongayong

https://www.kritike.org/journal/issue 26/payongayong june2020.pdf

ISSN 1908-7330

(cc) BY-NC-ND 


\section{REFLEXIVE-LIBERATIVE FILIPINO FEMINIST ETHICS}

liberative aspect. Being a feminist means there is recognition of the fact that women suffer from inequality, and there is conscious effort to change this situation.

Society's emphasis on marriage as a symbol of intimacy or intimate relationship has shifted with the rise of modern society. The concept of romantic love is present and is recognized in all cultures but, nowadays, it is not anymore necessarily linked to marriage. Some of the factors that contribute to this shift are the growing number of women who work outside the home, the rise of women's movements, and the spread of ideals of equality and rights.

Even in societies where marriage is still the rule, success in marriage is still considered as an end result of compatibility and companionship, rather than love and intimacy. Through the years, the presence of children adds up to the factors affecting successful marriages. In fact, it has become an extremely important consideration among couples' decision-making processes. In recent years, some unmarried couples (heterosexual or samesex) practice cohabitation or living-in. Such practice goes beyond societal approval and/or recognition.

The abovementioned are factors that affect Filipino feminists' reflexivity and liberality. These factors, or developments, serve as reasons for the changing contexts and ethics in lived feminisms. Though women are exposed to liberal ideas (i.e. academe, movements and organizations), some traditional concepts remain, such as comparing intimate relationships to property relations (thinking in terms of property, investment etc.); suffering in silence in the face of abuse, violence or neglect (afraid of being humiliated or putting the family name in a bad light); or passively accepting that infidelity is natural among men.

Also, society measures a woman in terms of her relationships-if these relationships are long and fruitful (successful) or if they are short and fleeting (frowned upon) and by extension, the type of family a woman is able to manage/foster. If it becomes a 'broken family', this is perceived as a 'failure', the burden of which rests solely on the woman. While some women unconsciously hope for their version of happily-ever-after, of a man that will come along and 'take care of them,' others women realize that this could turn out to be a painful illusion if taken too far, thus, they would rather be their own person-a whole, fully-functioning being, rather than half of one.

Inside the family, each member has very defined roles based on society's expectations and standing mores. As women, they are expected by society to perform certain roles - care giver, nurturer, teacher, and household manager while the men/husbands are expected to be providers for the family unit. Though, as feminists, they express dissatisfaction in being relegated to such roles, they still conform to such expectations. Some do try to re-invent

(c) 2020 Ma. Theresa T. Payongayong

https://www.kritike.org/journal/issue 26/payongayong june2020.pdf

ISSN 1908-7330

(c) $)$ BY-NC-ND 
these roles. Affluent women are able to hire helps to do the 'drudgery of housework' but this arrangement is far from the ideal, as it may also become a source of conflict later on.

Here are some snippets of Filipino feminists' lives from which a reflexive-liberative ethics has emerged:

1. The self-identifying feminist's lived experiences opened this woman's eyes to feminism. However, she has forgone formal membership to an organization of feminists. Her relationship reflects contrasting attitudes. For instance, possessing nontraditional views on marriage as an institution, possessing strength to let go of an unfaithful partner but takes back her partner, in spite everything, exhibiting the commonly-held attitude of married women to make the relationship work no matter what.

2. Her upbringing is reflected on her present family set-up. Her grounding in activism only strengthened the egalitarian nature of their family. She views feminism as a significant part of the struggle. Despite this, it shows that there are certain attitudes that do not depart from the norm: the double burden of wife and mother and the instances where she puts herself second.

3. Her upbringing, and her eventual exposure to social action and activism lay the foundation for her entry into an institution that seeks to empower workers through education. In the process, she found herself involved in gender and women's issues. It was not easy to gain the support and trust of the workers as they were too conservative and too patriarchal in managing the unions. But they eventually came to appreciate the work that the gender program does for them.

4. This was the backdrop of her personal life: family life and home life. She tries to do as she preaches such as raise her daughter cognizant of gender issues and conduct her relationship with her husband on equal footing.

5. Her upbringing, which was largely sheltered and privileged, hinged upon the importance of maintaining an honorable family name, and that one should always be cognizant of outward signs of good behavior and consideration for others.

6. Through her exposure in UP, she realized that she agreed with feminist ideas. This was done through a combination of academic learning, exposure to social realities of the volatile social situation at the time, and intensive reflection of her own life experiences. Although, this operates on an individual level and

(c) 2020 Ma. Theresa T. Payongayong https://www.kritike.org/journal/issue 26/payongayong june2020.pdf ISSN 1908-7330 
never channeled through a formal setting such as an organization or movement.

7. Her openness and ideal of equality and justice led her to pursue social work in the context of a religious order. The training inside the convent and the orientation towards the poor only deepened her understanding of what it means to do God's work in the face of injustice and oppression brought on by the Marcos regime.

8. She went against the common concept of being a nun, of the religious being concerned with purely religious matters and becoming politically conscious as she joined in the struggle with urban poor as well as workers.

9. In time, she would realize that aside from societal inequality, there is gender inequality. In fact, her fight for justice now translates to fighting in behalf of the neglected half of society, the women.

10. Her feminist ideas were an offshoot of her involvement in the movement and its work to uplift oppression. She tried to apply this to her personal relationship as well as to her role as a mother.

11. Later in life, she admits that she performs traditional gender roles but seeks to stay true to her feminist ideals despite the change in circumstance.

12. Her parents and the values that they inculcated were the main influences in her life. Her entry to the social movement is due to her father's pro-poor stance and strong sense of justice in the face of oppression. Her alternative child-rearing techniques and efforts to mainstream women's issues is both a result of her upbringing in a very strict and patriarchal household; as well as issues arising from her lived experiences in the social movement.

13. In the end, she, along with like-minded women, blazed the trail for a lot of firsts, breaking ground to take women's issues to the public arena to be debated and discussed and acted on.

14. Being sensitized to women's issues and women's oppression, she has carried over this framework in her work in broadcast media, using the broadcast medium to inform, influence and hopefully, change the way women are being portrayed in television. In the process, she also aims to teach all the people working with her, by example, what is the right way to treat women.

15. Her relationship with fellow activists broke conventions at the time and went against the sensibilities of her religious mother but eventually sensitized her to take on the calling of teaching feminism in her alma mater. Her keen intellect and participatory and pluralist attitude were what she brought on board in 
teaching feminism. She endeavors to sensitize her class not only to book theories but to their practical translation on the field via exposure to grassroots organizations.

16. She credits her relationship's success to application of feminist values that is reflected in the kind of upbringing she applied on her three children.

17. Her marriage to a revolutionary only enhanced her personal as well as their political involvement. Their children were strongly exposed to nationalist ideals as well as to the idea of serving the masses. Their egalitarian upbringing was also due to her belief in feminist ideals.

18. Although she is a loving mother, she was no typical wife, as she had her own life to live and no appendage or prop to her husband.

19. She continued her involvement to encompass not only women's issues but also issues like economic justice and development.

Culture, religion and education heavily dictate how a woman is treated in society. But once circumstances are changed i.e. a stay-at-home mom suddenly working or going back to school, other changes in their home life emerges. And no longer does the same conservative ideas apply. Though the self-identifying feminists are trying to change the traditional roles that women play both inside and outside the home, this remains a monumental task as they cannot truly break free of all deeply-ingrained conservative cultural conditioning, unless a more comprehensive change is forthcoming.

Throughout history, the role and status of Filipino women have slowly changed from non-participation in economic and political spheres, and confinement to domestic life, to their politicalization and involvement in the feminist movement to a great extent. Filipino women's reactions to their experiences of the patriarchal culture have also slowly changed their characteristics from being weak, submissive and passive to being strongwilled, independent and critical.

Indeed, history has taught Filipino women how they ought to live their lives. Everyday is a struggle in feminists' lives. They deal with ethical issues mindful, not only of their own, but also, of the collective good. The reflexive-liberative Filipino feminist ethics emphasizes choice and when applied, will lead to a more caring and just society. This kind of ethics could further shape the contours of feminism in the Philippines and provide guidance as to how women ought to act and work to further achieve empowerment. 


\section{REFLEXIVE-LIBERATIVE FILIPINO FEMINIST ETHICS}

\section{Recommendations}

Based on the findings, two topics deserve further exploration, i.e., feminist spirituality, and the reflexivity of the nationalist and feminist movements. It will be very interesting to account for spiritual journeys of prominent women in the context of their feminism. At the same time, it is important to challenge the ethics of nationalist and feminist movements from time to time and be able to engage in critical self-reexamination.

It is also recommended that a similar research be conducted, this time with self-identifying feminist participants from the Visayas and Mindanao areas and later on, from other Southeast Asian countries.

Department of Philosophy, University of the Philippines Diliman

\section{References}

Eviota, Elizabeth V., ed., Sex and Gender in Philippine Society: A Discussion of Issues on the Relations Between Men and Women (Manila: National Commission on the Role of Filipino Women, 1994).

Garcia-dela Cruz, Jesselynn, The Woman of Faith Today: Shaping the Nation's Future, (Quezon City: Office on Women, CBCP, 1999).

Gilligan, Carol, In a Different Voice: Psychological Theory and Women's Development (Cambridge, Mass.: Harvard Univ. Press, 1982).

"In a Different Voice: Women's Conceptions of Self and of Morality," in Women and Values: Readings in Recent Feminist Philosophy, $3^{\text {rd }}$ ed., ed. by Marilyn Pearsall (USA: Wadsworth Publishing Company, 1999).

Guerrero, Sylvia, ed., Towards Feminist Consciousness: Filipino Mothers and Daughters Tell their Story, (Quezon City: University Center for Women Studies - UP Diliman, 1997).

Noddings, "Ethics from the Standpoint of Women" in Women and Values: Readings in Recent Feminist Philosophy, $3^{\text {rd }}$ ed., ed. by Marilyn Pearsall (USA: Wadsworth Publishing Company, 1999).

Norman, Richard The Moral Philosophers: An Introduction to Ethics, $2^{\text {nd }}$ ed. (New York: Oxford University Press, 1998).

Paredes-Canilao, Narcisa, "Ethics in Feminist Research," in Gender-Sensitive E Feminist Methodologies: A Handbook for Health and Social Researchers, ed. by Sylvia H. Guerrero (Quezon City: University Center for Women's Studies - UP Diliman, 1999).

Roces, Mina, "Beauty Queen, Moral Guardian, Inang Bayan, and Militant Nun: Images of Female Power in Postwar Philippines, " in Researching the Fragments: Histories of Women in the Asian Context, ed. by Carolyn

(c) 2020 Ma. Theresa T. Payongayong

https://www.kritike.org/journal/issue 26/payongayong june2020.pdf

ISSN 1908-7330

(cc) BY-NC-ND 
Brewer and Anne-Marie Medcalf (Quezon City: New Day Publishers, 2000).

Women, Power, and Kinship Politics: Female Power in Postwar Philippines (London: Praeger, 1998).

Sterba, James P., Three Challenges to Ethics: Environmentalism, Feminism and Multiculturalism, (NY: Oxford University Press, 2001).

Torres, Amaryllis T., "Coping Strategies of Female-Headed Households in Urban Poor Communities in the Philippines" in Review of Women's Studies, 4:1 (1994).

Torres, Amaryllis T., Marlene G. dela Cruz, and Thelma B. Magcuro, Mga Ina ng Bayan: Life Stories of Filipino and Japanese Women Community Leaders (Quezon City: Milflores Publishing Inc., 2002).

Walker, Margaret Urban, Moral Understandings: A Feminist Study in Ethics, 2nd ed. (Oxford: Oxford University Press, 2007).

\section{Research Data Sources}

Focus Group Discussion (FGD) on Family Life 1

Focus Group Discussion (FGD) on Family Life 2

Focus Group Discussion (FGD) on Intimate Relationships 1

Focus Group Discussion (FGD) on Intimate Relationships 2

Life Story Interviews with ten (10) self-identifying feminists

(c) 2020 Ma. Theresa T. Payongayong

https://www.kritike.org/journal/issue 26/payongayong june2020.pdf

ISSN 1908-7330

(cc) BY-NC-ND 